特集 * 鉄筋コンクリート構造物の塩害劣化 $/ \mathrm{IV}-7.2$

\title{
フレッシュコンクリート中の 塩化物の試験方法
}

福 島 敏 夫*

1.はじめに

コンクリート中に含まれる種々の形態の塩化物から供 給される塩素イオンは，内部鉄筋の腐食を促進してコン クリート構造物を早期に劣化させ，塩害として大きな社 会問題となっている。この塩害に対する有益な対策のた めには，まずは打設前のフレッシュコンクリート中の塩 化物量を，内部鉄筋の腐食のおそれのない一定量以下に 制限する必要がある。建設省でも，この塩害対策の一環 として, 昭和 61 年 6 月に建築指導課長通達「コンクリ 一ト中の塩化物総量規制基準」が出され，周知徹底がは かられた。しかし，そのための基礎として，コンクリー ト中の塩化物の総量を簡易にかつ精度よく測定できる試 験法の確立が必要である。

フレッシュコンクリート中の塩化物量を測定する場合 には, ブリージング水または吸引ろ過によって得られる ろ液に刘して塩素イオン濃度を測定し, 単位水量を掛け ることにより単位容積または単位重量当りの塩化物量に 換算することになる。従来, 塩素イオン濃度の測定に は, モール法 (硝酸銀滴定法), 電位差滴定法, 吸光光 度法 (チオシアン酸第二水銀法) 等の各種の化学分析法 が広く使われてきた。これらの化学分析法は，一般的に 精度よい結果が得られるが, 分析用試験液の調整に手間 がかかったり，化学的知識と熟練した技術を必要とする 面もあり，必ずしも簡易な測定法とは言えなかった。と くに，今日使用されるコンクリートのほとんどがレデー ミクストコンクリート（生コン）となっている現状で は, フレッシュコンクリート中の塩化物の総量を工事現 場で十分な精度で迅速かつ簡易に測定するための機器の 開発が望まれていた。この要請を受けて，民間各社がコ

*ふくしま・としお／建設省建築研究所第 2 研究部アイソト ープ研究室長
ンクリート中の塩化物量簡易測定器の開発を行い，その らちの有効ないくつかの機種に対しては，その性能に関 して，(射国土開発技術研究センターにおいて技術評価が 行われ、コンクリート中の塩化物総量規制を行うための 基礎が整備された。

ここでは, フレッシュコンクリート中の塩化物の試験 法として, まずは従来の化学分析法の特徴と原理につい て概略し, 次いで, (財国土開発技術研究センターにおい て技術評価を受けたコンクリート中の塩化物量簡易測定 器の基礎をなす典型的な 4 つの測定原理と, それに関連 した測定上の留意点について述べることにする。

2. 化学分析法による塩化物試験法の特徴 と原理

従来から使用されている化学分析法による塩化物試験 法には, (1)重量法, (2)容量法, (4)吸光光度法, (4)電気分 析法, (5)放射化分析法, (6イオンクロマトグラフィー法 などがある。(2)の容量法には，aモール法，b．ホルハ ルト法，c. フィヤン法，d. 硝酸第 2 水銀法が含まれ， (3)の吸光光度法には, チオシアン酸第二水銀法とクロム 酸銀法がある。(4)の電気分析法は, a. 電位差滴定法, b. イオン電極法, c. 伝導度滴定法, d. 電量滴定法など に分類される。

このらち，一般的によく使用されるモール法，吸光光 度法, 電位差滴定法および放射化分析法の $4 つ を$ 選ん で, その特徴と原理について, やや詳しく述べることに する。

\section{1 モール法}

モール法は銀イオンによる沈殿滴定法の一種であり， クロム酸カリウムを指示薬として, 硝酸銀溶液で塩素イ オンの定量をする。クロム酸イオン存在下で塩素イオン を含む溶液に銀イオン溶液を滴下していくと，塩化銀 


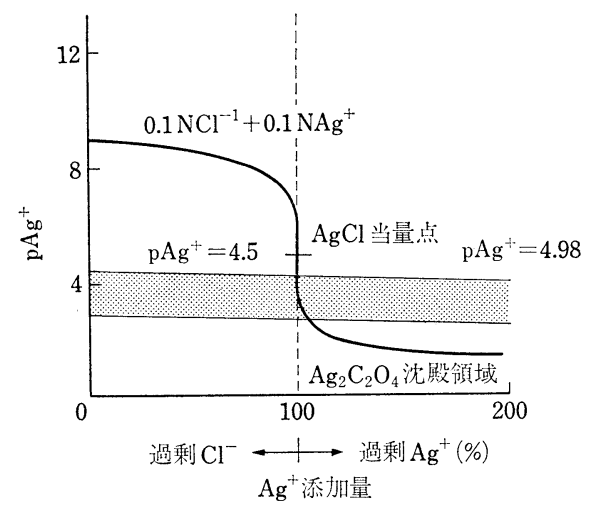

図一1 モール法による沈殿滴定の概念図 $\left(0.1 \mathrm{NCl}^{-}\right.$を $0.1 \mathrm{NAg}^{+}$で滴定する場合 $)$

$(\mathrm{AgCl})$ の方がクロム酸銀よりも溶解度が小さいため に，塩化銀が沈殿し終わってから，赤褐色のクロム酸銀 $\left(\mathrm{Ag}_{2} \mathrm{CrO}_{4}\right)$ が沈殿する。したがって，この着色点を終 点とするものである。このモール法による沈殿滴定の概 念図を図一1 に示す。当量点近傍では, 塩素イオン濃度 が急激に減少し，同時に銀イオン濃度は急激に増加す る。あらかじめ加えられるクロム酸イオンの濃度は，だ いたい $10^{-2} \mathrm{~N}$ (規定) である。 $\mathrm{Ag}_{2} \mathrm{CrO}_{4}$ の溶解度積は $9 \times 10^{-12}$ であるから, $\mathrm{AgCrO}_{4}$ の沈殿を起こすのに必 要な銀イオン濃度 $\left[\mathrm{Ag}^{+}\right]$は,

$$
\left[\mathrm{Ag}^{+}\right]=\sqrt{9 \times 10^{-12} / 10^{-2}}=3 \times 10^{-5} \mathrm{~N}
$$

したがって銀イオン指数 $\mathrm{pAg}^{+}$は,

$$
\mathrm{pAg}^{+}=-\log \left[\mathrm{Ag}^{+}\right]=4.5
$$

となり, 塩素イオンによる当量点の $\mathrm{pAg}^{+}=4.98$ より 小さくなる。換言すれば，当量点を過ぎてから，さらに 微量の銀イオンを加えた時に赤褐色の沈殿を生じ, 終点 を認めることになるか, その過剩量は $0.1 \mathrm{~N}$ の銀イオ ン溶液の滴下量で $0.03 \mathrm{~m} l$ 位であり, だいたい 容量分 析の精度の程度となるので, 実用上は問題とならない。 モール法の最適水素イオン指数 $\mathrm{pH}$ は 6.5 10.5 の範 囲である。酸性であると,

$$
\mathrm{CrO}_{4}{ }^{2-}+\mathrm{H}^{+} \rightleftarrows \mathrm{HCrO}_{4}
$$

の平衡が右に進み，クロム酸銀が溶解してしまう。また アルカリ性が強いと, 酸化銀 $\left(\mathrm{Ag}_{2} \mathrm{O}\right)$ や炭酸化銀 ( $\mathrm{Ag}$ $\left.\mathrm{CO}_{3}\right)$ が沈殿して, 誤差の原因となる。モール法による 塩素イオンの定量下限は $20 \mathrm{ppm}$ であり, 微量分析には 適さない。

\section{2 吸光光度法}

塩素イオンと金属塩との反応に伴って生成する金属錯 イオンの特性吸収波長領域における吸光度を測定するこ とにより, 反応した塩素イオンの定量を行うものであ る。錯イオンを含む溶液の濃度を $C(\mathrm{~mol} / \mathrm{l})$, 吸光セル 中の溶液層の厚さを $l(\mathrm{~cm})$, 特性吸収波長におけるモル
吸光係数を $\varepsilon\left(\mathrm{cm}^{2} / \mathrm{mol}\right)$ ，入射した光の強さを $I_{0}$ (Joule/ $\mathrm{s})$, 透過した光の強さを $I$ (Joule/s) とすれば， $C$ が薄 い領域では, 次の Lambert-Beer の法則が成り立つ。

$$
\begin{gathered}
I=I_{0} \exp (-\varepsilon C l) \\
\text { したがって, } \log \left(I_{0} / I\right)=\varepsilon C l
\end{gathered}
$$

$\log \left(I_{0} / I\right)$ を吸光度といい，これを 分光光度計で求め れば，先の関係から錯イオンのモル濃度 $C$ が分かり，さ らに反応した塩素イオン濃度を求めることができる。こ の時, 吸光度とモル濃度の関係を検量線を用いて求める が, 試料溶液が高濃度になると, 直線関係からずれてく ることがあり，誤差を生じやすいので，試料溶液を希薄 領域にする必要がある。吸光光度法のうちには，チオシ アン酸第二氷銀法とクロム酸銀法とがある。前者の方法 では, 試料溶液にチオシアン酸第二水銀を加え, 溶液中 の塩素イオンを塩化第二水銀とし，この時生ずるチオン シアン酸イオンとあらかじめ加えてある硫酸第二鉄アン モニウムの第二鉄アンモニウムイオンが反応して生ずる チオシアン酸第二鉄アンモニウムイオンの赤色錯イオン の $460 \mathrm{~nm}$ の特性吸収波長で吸光度を測定する。塩素イ オンの 定量下限は $0.1 \mathrm{ppm}$ で微量分析に適しているた め, 工業用水中の塩素イオン定量法 (JIS K 0101) に採 用されている。また, 後者の方法では, クロム酸銀を加 えて溶液中の塩素イオンを塩化銀に転化した時に遊離す るクロム酸イオンの特性吸収波長 $366 \mathrm{~nm}$ および 405 $\mathrm{nm}$ で吸光度測定を行い，塩素イオン濃度に換算する。 塩素イオンの定量限界は $1 \mathrm{ppm}$ である。

(a)

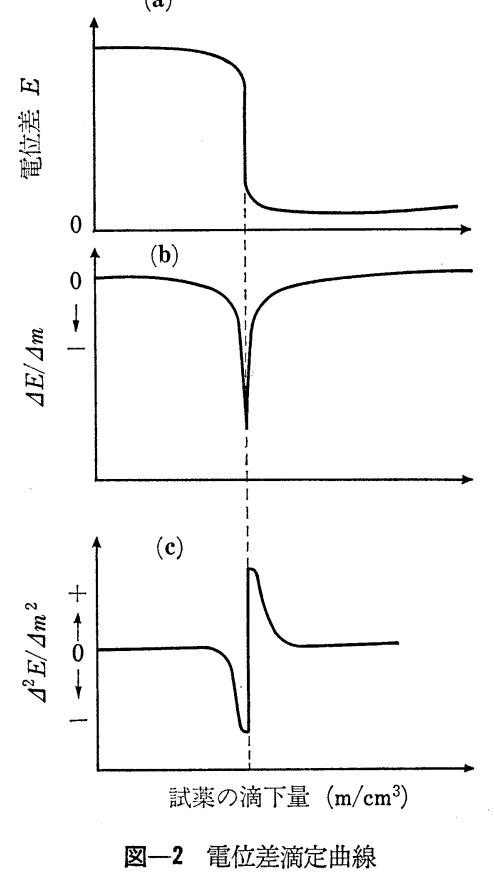

コンクリート工学 


\section{3 電位差滴定法}

硝酸銀溶液を用いて塩素イオンの定量を行う沈殿滴定 法において, 当量点近傍で, 被滴定試薬の活量 (活動度 ともいう。熱力学的諸関係に打いて，濃度そのものを用 いると質量作用の法則のような簡単な関係が成立しにく くなるため, 簡単な補正をした熱力学的濃度というべき もの）に急激な変化が生ずるので, 適当な指示電極（塩 素イオン選択性電極）を用いてそれの平衡電極電位を測 定すると，Nernst の式で表されるように活量の関数と なるため, 当量点付近で急変する (図一2)。この現象を 用いて, 滴定量と電極電位との関係を追跡して, その最 も変化の大きくなる点を終点として当量点を求める滴定 法を電位差滴定法という。この方法は, 適当な指示薬が ない場合でも滴定反応に利用でき，また，終点を目視で 判断するのではないために, 微量分析にも適する。試薬 の滴下量と平衡電位差との関係を示す典型的な電位差滴 定曲線は図一2（a）に示される。同図の変曲点を求めて 終点とするが, 変曲点が明確でない場合には, 図一2 (b) の一次微分曲線, または, (c) の二次微分曲線を求めて 終点を決定する。自動電位差滴定装置では，これらの滴 定操作がすべて自動化され, 迅速かつ正確に滴定を行う ことができる。通常, 指示電極の電位の測定法は, 一定 の電位を示す参照電極と組み合わせて電池を作り，両極 間に流れる電流がゼ口になるようにして測定するので, 零電流電位差滴定法とも言われる。しかし，電極反応が 遅く不可逆であるような場合には，平衡電位の測定に時 間がかかり，その変動も敏感でない。このために，両極 間に一定の微弱電流を流して，指示電極が分極された状 態で測定される方法もあり, これを定電流電位差滴定法 という。

\section{4 放射化分析法}

塩素の原子核に中性子を衝突させて生成する放射性同 位元素が $\gamma$ 線を放射する原子核反応 ${ }^{37} \mathrm{Cl}(n, r){ }^{38} \mathrm{Cl}$ を利 用する (半減期 : $\lambda=37.3 \mathrm{~min}, r$ 線エネルギー : $E_{1}=$ $1.643 \mathrm{MeV}, E_{2}=2.168 \mathrm{MeV}$ )。放射性核種の示寸放射 能の強さを測定することにより, 塩素の定量分析に用い る。この分析法はきわめて感度が高く(0.01 0.1 $\mu \mathrm{g}$ ま で検出可能)，試料の前処理を必要としないという利点 があるが，放射能が弱くなるに従って誤差が大きくな り，精度が低くなる。このため, 既知量の目的元素を含 む試料と並べて同時に同一条件で照射し，生成する放射 能を同一の条件で測定して比較する相対法が利用され る。禋準試料中の定量すべき塩素の重量を $W_{0}$, 生成核 種の放射能を $A_{0}$, 測定試料中の塩素の重量を $W$, 生成 核種の放射能を $A$ とすれば,

$$
W=W_{0} \times A / A_{0}
$$

となる。

Vol. 25, No. 11, Nov. 1987
3. フレッシュコンクリート中の塩化物簡 易測定器

フレッシュコンクリート中の塩化物含有量を簡易に測 定する機器の開発に関しては, 最初, 昭和 59 年度建設 省建設技術評価制度の課題として取り上げられ，いくつ かの機器の評価申請があったが，その時点では, 開発目 標のすべての項目について要求性能を満足するものがな かった。その後, 申請した各社では, 精度向上を含む実 用化に向けての研究の努力が続けられ，一方，(財国土開 発技術研究センターに設置された技術評価委員会 (委員 長：岸谷孝一東京大学教授 (当時)) および専門委員会 （部会長 : 福島敏夫）で, 開発目標が達成されなかった 点などについて検討を加え, 新たな評価が行われ, 表一 1 に示す 10 社 11 機種が要求性能を満足しているとの 評価がなされた（他の機種についても継続的に評価作業 が行われている)。同センターにおける評価において， 測定器に対する要求性能としては, フレッシュコンクリ 一ト中の塩化物総量規制の設定範囲 $\left(0.3 \sim 0.6 \mathrm{~kg} / \mathrm{m}^{3}\right)$ に対応して, 水溶液中の塩素イオン濃度 $0.1 \sim 0.5 \%$ ( $\mathrm{Cl}^{-} /$水) の範囲内で， 測定誤差が基準值の $\pm 10 \%$ 以 内になることとした。基準值としては, フレッシュコン

表一1 技術評価を受けた塩化物簡易測定器の概要

\begin{tabular}{|c|c|c|c|}
\hline 測 定 器 名 & メーカー名 & 测 定 原 理 & 測 定 方 法 \\
\hline $\begin{array}{l}\text { 塩分量测定計 } \\
\text { カンブ }\end{array}$ & 䛈)小野田 & モール法の応用 & $\begin{array}{l}\text { 試験紙を生コン } \\
\text { 中に挦入 }\end{array}$ \\
\hline $\begin{array}{l}\text { 北川式塩分検知 } \\
\text { 管 SL 型 }\end{array}$ & $\begin{array}{l}\text { (姝)光明理化学工 } \\
\text { 業 }\end{array}$ & モール法の応用 & 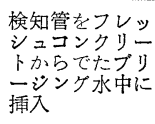 \\
\hline $\begin{array}{l}\text { 塩分濃度計 } \\
\text { ソルターC-9 }\end{array}$ & 姝吉川産業 & 電極電流測定法 & $\begin{array}{l}\text { 試料を専用カッ } \\
\text { プに採取し, 万 } \\
\text { 液中に電極を㨉 } \\
\text { 入 }\end{array}$ \\
\hline $\begin{array}{l}\text { 塩分濃度計 } \\
\text { ソルメイ }-100\end{array}$ & $\begin{array}{l}\text { (姝)朝日ライフン } \\
\text { イエンス }\end{array}$ & 䉓量滴定法 & 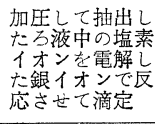 \\
\hline $\begin{array}{l}\text { 垍分濃度㖕 } \\
\mathrm{V}-7 \mathrm{CL}\end{array}$ & (姝)堀場製作所 & $\begin{array}{l}\text { 䧿択性イオン電 } \\
\text { 極法 }\end{array}$ & $\begin{array}{l}\text { 電極をフンレッン } \\
\text { ユコンクリート } \\
\text { 中に插入 }\end{array}$ \\
\hline $\begin{array}{l}\text { 程分濃度計 } \\
\text { CS-10A }\end{array}$ & (洙)東亚電波工業 & $\begin{array}{l}\text { 選抧性イオン電 } \\
\text { 極法 }\end{array}$ & $\begin{array}{l}\text { 電極をフンレッン } \\
\text { ユコンリート } \\
\text { 中に挿入 }\end{array}$ \\
\hline $\begin{array}{l}\text { 塩分濃度計 } \\
\text { SALT-99 }\end{array}$ & \multirow{2}{*}{$\begin{array}{l}\text { 㮫東興化学研究 } \\
\text { 所 }\end{array}$} & \multirow{2}{*}{$\begin{array}{l}\text { 選択性イホン電 } \\
\text { 極法 }\end{array}$} & \multirow{2}{*}{ 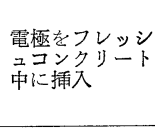 } \\
\hline $\begin{array}{l}\text { 塩分濃度計 } \\
\text { SALT }\end{array}$ & & & \\
\hline $\begin{array}{l}\text { 塩分濃度計 } \\
\text { ソルコン } \\
\text { CL-1 A }\end{array}$ & (珠)理研計器 & $\begin{array}{l}\text { 選択性イオン電 } \\
\text { 極法 }\end{array}$ & $\begin{array}{l}\text { 電極をフレレッン } \\
\text { ユコンリート } \\
\text { 中に插入 }\end{array}$ \\
\hline $\begin{array}{l}\text { 塩分濃度計 } \\
\text { PCL-1 }\end{array}$ & (侏)電気化学計器 & $\begin{array}{l}\text { 選択性イオン電 } \\
\text { 極法 }\end{array}$ & $\begin{array}{l}\text { 電極をフレンッン } \\
\text { ユコンクート } \\
\text { 中に挿入 }\end{array}$ \\
\hline $\begin{array}{l}\text { 塩分濃度計 } \\
\text { CL-203 }\end{array}$ & (蛛)笠原理化工業 & $\begin{array}{l}\text { 選択性イオン電 } \\
\text { 極法 }\end{array}$ & $\begin{array}{l}\text { 電極をフンレッン } \\
\text { ユコンクリト } \\
\text { 中に挿入 }\end{array}$ \\
\hline
\end{tabular}


クリートから吸引ろ過して得られるろ液に対して，モー ル法, チオシアン 酸第二水銀吸光 光度法, 電位差滴定 法, 硝酸第二水銀法などの化学分析法を用いて得られる 値とした。これらの分析法による測定值は最大 10 数 \% の差を生ずることもあるが，平均してみると，いずれの 分析法の值も大差がないことが確認されている。要求性 能は, 上記の測定誤差に関するもの以外に, 機器の取扱 いが簡便で短時間で結果が得られること，十分な耐久性 をもつことなどが条件となっていた。評価を受けた塩化 物簡易測定器の測定原理は, (1)モール法の応用（検知管 式), (2)電極電流測定法, (3)電量滴定法, (4)イオン選択 性電極法の 4 種類に大別される。いずれの測定法におい てもフレッシュコンクリートの塩素イオン濃度を正確に 反映させるために，ブリージング水やろ液の採取等のサ ンプリングにおいて誤差の伴わないような工夫が必要で あり，生コンクリート中に直接測定器を挿入する方式で は，その均一性に留意する必要がある。検知管式では， サンプルの 3 点以上で測定を行い平均を取ることによ り, 空間的均一性を確保する必要がある。電極電流測定 法では, 時間的平均を行い, 測定值の時間的変動を消去 する必要がある。また，測定温度による誤差をなくすた めの温度補正が必要となるが，検知管式を除き，温度補 償回路が内蔵されているものが多い。以下に，これら 4 つの測定原理の特徴と留意点について述べる。

\section{1 モール法の応用(検知管式)}

重クロム酸銀をしみ込ませたろ紙をプラスチック片ま たはガラス管に封入して，これをフレッシュコンクリー ト中に差し込むと, 監素イオンを含む溶液が茶褐色の重 クロム酸銀 $\left(\mathrm{Ag}_{2} \mathrm{Cr}_{2} \mathrm{O}_{7}\right)$ と次の反応を起こし，塩化銀を 生成して白変しながら吸い上げられてゆく。

$$
\mathrm{Ag}_{2} \mathrm{Cr}_{2} \mathrm{O}_{7}-2 \mathrm{Cl}^{-} \longrightarrow 2 \mathrm{AgCl}+\mathrm{Cr}_{2} \mathrm{O}_{7}{ }^{2-}
$$

塩素イオンがすべて反応して検知管が白変した部分の 長さは, 塩素イオン濃度と一対一対応にあるので, 反応 終了時の目盛により, 塩素イオン濃度を\%表示で直続で きる。この時, 吸上げ口に粒子が目詰りすると, 誤差の 原因となりやすいので，その工夫がなされている。使い 捨てで, 他に消耗品も不用で安価であるが, 生コンに試 験紙を直接挿入する方式の場合には，測定值を読み取る まで十分な待期時間を要する (20 30 分)。また, 試験

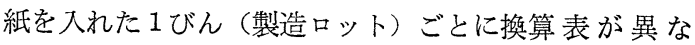
り, 暗所に保存して 1 年以内のものでないと劣化してい る場合があるので留意する必要がある。

\section{2 電極電流測定法}

塩素イオンを含む溶液中に銀電極を挿入し，対極との 間に一定電圧を加えると, 電極付近で次のような酸化還 元反応を生ずる。

酸化反応 $\mathrm{Ag}+\mathrm{Cl}^{-} \longrightarrow \mathrm{AgCl}+\mathrm{e}^{-}$
還元反応 $\mathrm{AgCl}+\mathrm{e}^{-} \longrightarrow \mathrm{Ag}+\mathrm{Cl}^{-}$

電極反応が十分速く, 反応物や生成物の拡散が律速的 であるとすれば，非定常拡散を考慮すると，電極表面で の酸化還元電流法次のコットレルの式で表せる。

$$
i=n F A D C / \sqrt{\pi D t}
$$

ここで, $i:$ 測定限界電流, $t:$ 測定時間, $n:$ 電極に 関与する電子数で, この場合は $1, A$ : 電極表面積, $D$ : 塩素イオンの拡散係数で, 標準溶液を用いて検量線を作 成することにより一定とすることができる，F：ファラ デー定数， $\pi$ : 円周率， $C$ : 塩素イオン浱度。また, $\sqrt{\pi D t}$ は長さの次元をもち，拡散層の厚さに対応する。

この式を利用すると, 酸化還元電流は塩素イオン濃度 に比例し, 測定時間の平方根に反比例することになり, 一定時間後にこの電流を測定することにより，塩素イオ ン濃度が測定できることになる。この原理を応用した塩 化物簡易測定器は, 測定時間は約 1 分位で迅速である が，溶液を酸性にするための前処理が必要である。

\section{3 電量滴定法}

電解用銀線をアノード電極とし, カソード銀電極との 間に一定電流を流して電気分解によって銀イオンを発生 させ, 溶液中の塩素イオンと反応させる。塩素イオンが なくなった時点で, 過剩に存在する銀イオンによる電気 伝導度や電位差の急激な変化を検知して電気分解を停止 させる。この時流した電流を $i$ とし，停止までの時間を $t$ とすると, ファラデーの法則により, この間に発生し た銀イオンは， $i t / F$ グラム当量であり，これはまた， 反応した塩素イオンのグラム当量数に等しく，塩素イオ ン濃度に直接結びつけることができる。電量滴定の大き な特徴は, きわめて微量の滴定試薬を発生させることが できるために, 微量分析に適することであり, 定量限界 はむしろ終点決定法の精度や，万液採取量の精度によ る。この原理を応用した簡易塩化物測定器は, 比較的短 時間に精度よい測定を行うことを可能にしている。電極 は消耗品となる。フレッシュコンクリートから加圧によ りブリージング水を抽出する際に, 多少注意を要する。

\section{4 選択性イオン電極法}

塩素イオンに対して選択的に感応する塩素イオン選択 性電極と, 基準となる参照電極および温度補償電極とか ら構成される棒をフレッシュコンクリートに差し込み, 電位差を測定して, 塩素イオン濃度と関連づける。塩素 イオンの活量を $a$ とすると, Nernst の式により, 参照 電極との間に次の電位差を生ずる。

$$
\begin{aligned}
& E=E_{0}+2.303(R T / F) \log a \\
& E=E_{0}+0.059 \log a\left(25^{\circ} \mathrm{C} \text { の時 }\right)
\end{aligned}
$$

ここで, $E_{0}$ : 基準電位差 (イオン電極の組成・構造に よる固有の值) である。また活量 $a$ は, 塩素イオン濃度 $C$ との間に $a=r C(r$ : 活量係数 $)$ の関係にあり, これ 
から電位差を測定することにより塩素イオン濃度を求め ることができる。このイオン電極の電位差は, 塩素イオ ン以外に, 臭素イオンや硫黄イオンなどの妨害イオンが 存在すると, 次の形で影響を受ける。

$$
E=E_{0}+2.303(R T / F) \log \left(a+\sum_{l} k_{l} a_{l}\left(1 / n_{l}\right)\right)
$$

$k_{l}$ は妨害イオンの影響を示す值で, 選択係数と呼ば れ，この值が小さいほど塩素イオンに対する選択性がよ くなる。直接生コンクリート中に電極を差し込むという 簡便さのために, 塩化物簡易測定器には選択性イオン電 極法を応用したものが多いが，とくに高炉セメントによ るフレッシュコンクリートの場合には, 普通ポルトラン ドセメントによるフレッシュコンクリートの場合に比べ て $\mathrm{Br}^{-}, \mathrm{I}^{-}, \mathrm{S}^{2-}$ などの妨害イオンが多くなるため, 測 定值が高めになる傾苘がある。また，選択性イオン電極 は $\mathrm{pH}$ の影響を強く受け, 強アルカリ性の中では $\mathrm{pH} の$ わずかな変動により発生する電位が大きく変動する。高 炉セメントは, 普通ポルトランドセメントに比べて $\mathrm{pH}$ にわずかに差があり，測定值の誤差の原因となる。この ため, 発生する電位の安定化のために, イオン電極の内 部液の調整, 万液の $\mathrm{pH}$ の調整を行う等の工夫が必要と なる。(射)国土開発技術研究センターで技術評価を受けた 塩化物測定器は, 妨害イオンの影響の除去と $\mathrm{pH}$ の調整 に工夫をこらし，実用化をはかっている。

\section{<参考文献>}

1）日本分析化学会編 : 分析化学便覧 (改訂三版), pp. 191 $\sim 194$, 丸善, 昭 56.9

2）電気化学協会編：電気化学便覧 (第四版), pp. 137 217, 丸善, 昭 60.1

3）鎌田 仁：応用化学講座「分析化学-II」, pp. 1 146, ב 口ナ社, 昭 42.1

4) コンクリート中の塩分含有量測定器の技術評価書, 国土 開発技術研センター, 昭 61,62

5）小林堅次：建設技術評価一 コンクリート中の 塩分含有 量測定器の開発，建築技術，No. 410, pp. 81 84, 1985. 10

6）小林賢次 : 技術評価一 ユンクリート中の塩分含有量測 定器, 建築技術, No. 420 , pp. $77 \sim 80,1986.8$

7) 小林賢次 : 建設技術評価制度と 塩分含有量測定器, 七丈 ント・コンクリートNo. 477 , pp. 19〜25, 1986.10

8）柝田佳宽：フレッシュコンクリートの塩分含有量の試験 方法, コンクリート工学, Vol. 25, No. 2, pp. 26〜32, 1987.2

9）柝田佳寛：技術評価—コンクリート中の 塩分含有量測 定器, 建築技術, No. 430, pp. 191 194, 1987.6

10）福士 勲:これからの品質管理一塩化物含有量のチェ ック，建築技術，No. 431, pp. 111 114, 1987.7 